\title{
Weed species composition of agrophytocenoses in Altai Krai
}

\author{
Tatiana A. Terekhina', Alyona V. Nochevnaya ${ }^{2}$, \\ Natalia V. Ovcharova ${ }^{1}$, Irina A. Lapshina ${ }^{3}$
}

1 Altai State University, 61 Lenina prospect, 656049, Barnaul, Russia

2 Federal State Budgetary Institution "Central Scientific and Methodological Veterinary Laboratory", 4V Maksim Gorky str, 656056, Barnaul, Russia

3 Rosselkhoznadzor Administration for Altai Krai and Altai Republic, 65 Proletarskaya str, 656056, Barnaul, Russia

Corresponding author: Natalia V. Ovcharova (ovcharova_n_w@mail.ru)

Academic editor: D. German | Received 18 November 2020 | Accepted 2 April 2021 | Published 30 April 2021

http://zoobank.org/FE20DE53-A947-432E-8D26-60F541617CE6

Citation: Terekhina TA, Nochevnaya AV, Ovcharova NV, Lapshina IA (2021) Weed Species Composition of Agrophytocenoses in Altai Krai. Acta Biologica Sibirica 7: 93-102 https://doi.org/10.3897/abs.7.e60884

\begin{abstract}
The article reviews the weed species composition of oat, sunflower, wheat, buckwheat, rapeseed and flax agrophytocenoses on 390 fields in 21 districts of Altai Krai: Aleyskiy, Bistroistokskiy, Baevskiy, Burlinskiy, Kamenskiy, Kosikhinskiy, Krutikhinskiy, Kytmanovskiy, Loktevskiy, Mamontovskiy, Novichikhinskiy, Pankrushikhinskiy, Rebrikhinskiy, Rubtsovskiy, Shipunovskiy, Sovetskiy, Tretyakovskiy, Troitskiy, Tyumentsevskiy, Zarinskiy, and Zonalniy. The studied fields were surveyed by the route method, which involved the study of the plot by examining it along two diagonals and four sides, when the area did not exceed 20.0 hectares. Larger fields were divided into plots of 20.0 hectares before the survey. The areas adjacent to roads were examined most carefully, since it is often from the road that the field becomes infested. We used the ArcGis program to compile original maps for the main weed plant species. It was found that out of 45 species encountered, only 10 play a significant role in weed infestation and have a high frequency rate: aboriginal Convolvulus arvensis, Amaranthus retroflexus, Euphorbia virgata, Lathyrus tuberosus, Chenopodium album, as well as such adventive species as Fallopia convolvulus, Setaria pumila, Panicum miliaceum subsp. ruderale, Avena fatua and Echinochloa crusgalli. The largest number of species accounts for the Poaceae family (33.3\%). The Brassicaceae family is characterized by a slightly lower percentage of participation in the adventitious flora $(27.7 \%)$. Other families are not so well represented (by 1-2 species each).
\end{abstract}

Copyright Tatiana A. Terekhina et al. This is an open access article distributed under the terms of the Creative Commons Attribution License (CC BY 4.0), which permits unrestricted use, distribution, and reproduction in any medium, provided the original author and source are credited. 


\section{Keywords}

Agrophytocenosis, weeds, adventitious species, frequency rate

\section{Introduction}

The natural conditions of the modern world cause overwhelming changes in anthropogenic landscapes. The structure of fertile lands is disturbed and untended lands appear. Such lands are characterized by synanthropic vegetation, arising due to the active settlement of adventitious species.

The territory of Altai Krai is located within the forest-steppe and steppe zones, which have a submeridional orientation. The following types of vegetation are represented on the region territory: forests, steppes, meadows, swamps, tundra, shrub, rocky, aquatic, saline and synanthropic vegetation. The share of farmland is $67.7 \%$, plowed area is $39.7 \%$. Forest and tree-shrub vegetation $24.9 \%$, the rest of the vegetation does not exceed 9.4\% (Burlakova 2007). Tilling of wild and idle lands in Altai Krai accounted for the early 50 s of the last century.

The total area of the region land fund is 15799.6 thousand hectares. On the whole, the current ploughness totals up to $39.7 \%$ of the region area, whereas in the flat part of the region, basically all arable lands are tilled (Burlakova 2007). Meadows, dry and real steppes represent the steppe vegetation of Altai Krai. Their fragments have been preserved on the territory of the region. The current period is characterized by the presence of secondary steppes, which developed in the place of dry meadows, along the degraded primary steppes, in the sites of felled forests and on idle lands (Korolyuk et al. 2005).

Thus, our research aimed at analysis of weed species composition in the agricultural lands of Altai Krai and identification of the most dominant species.

\section{Material and methods}

The material for the study was the monitoring documents, in which lists of weed species were compiled for each field, indicating their abundance. These documents reflect the information on the weeds found in the agrocenoses of Altai Krai during the field surveys in August-September 2018 and July-September 2019. We processed 390 documents during the analysis of archival data for field work research. The team of the authors together with the staff of FSBI "Central Research Veterinary Radiologic Laboratory" surveyed 390 fields in 21 districts of the Altai Krai: Aleyskiy, Bistroistokskiy, Baevskiy, Burlinskiy, Kamenskiy, Kosikhinskiy, Krutikhinskiy, Kytmanovskiy, Loktevskiy, Mamontovskiy, Novichikhinskiy, Pankrushikhinskiy, Rebrikhinskiy, Rubtsovskiy, Shipunovskiy, Sovetskiy, Tretyakovskiy, Troitskiy, Tyumentsevskiy, Zarinskiy, and Zonalniy (Fig. 1). 


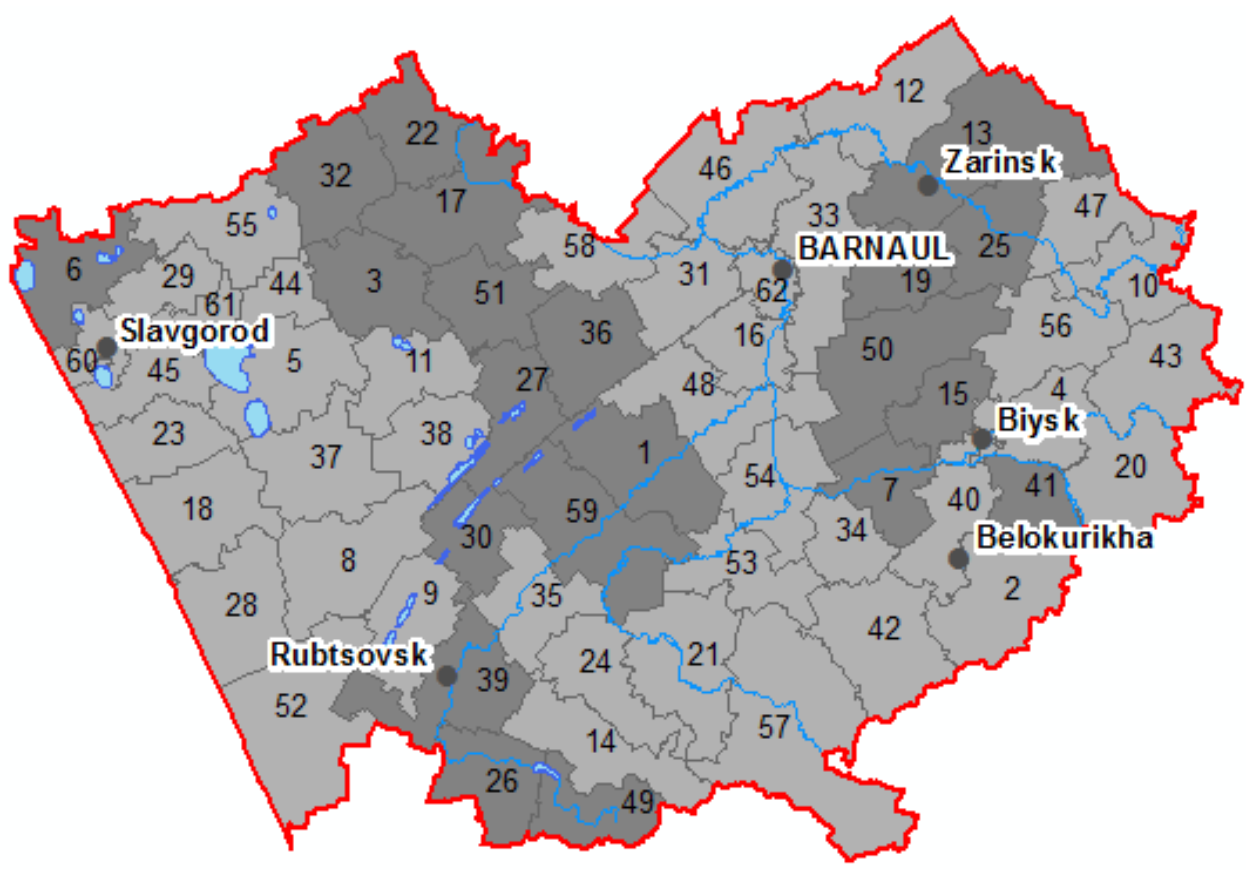

Figure I. Base map of the studied areas in Altai krai. Areas in which the research was carried out are highlighted in a darker color. The numbers on the map represent the districts: I - Aleysky; 2 - Altaysky; 3 - Bayevsky; 4 - Biysky; 5 - Blagoveshchensky; 6 - Burlinsky; 7 - Bystroistoksky; 8 - Volchikhinsky; 9 - Yegoryevsky; 10 - Yeltsovsky; I I - Zavyalovsky; I 2 - Zalesovsky; I 3 - Zarinsky; I 4 - Zmeinogorsky; I 5 - Zonalny; I 6 - Kalmansky; I 7 Kamensky; $I 8$ - Klyuchevsky; 19 - Kosikhinsky; 20 - Krasnogorsky; 2 I - Krasnoshchyokovsky; 22 - Krutikhinsky; 23 Kulundinsky; 24 - Kuryinsky; 25 - Kytmanovsky; 26 - Loktevsky; 27- Mamontovsky; 28 - Mikhaylovsky; 29 - Nemetsky National; 30 - Novichikhinsky; 3 I - Pavlovsky; 32 - Pankrushikhinsky; 33 - Pervomaysky; 34 - Petropavlovsky; 35 - Pospelikhinsky; 36 - Rebrikhinsky; 37 - Rodinsky; 38 - Romanovsky; 39 - Rubtsovsky; 40 - Smolensky; 41 - Sovetsky; 42 - Soloneshensky; 43 - Soltonsky; 44 - Suyetsky; 45 - Tabunsky; 46 - Talmensky; 47 - Togulsky; 48 - Topchikhinsky; 49 - Tretyakovsky; 50 Troitsky; 5 I - Tyumentsevsky; 52 - Uglovsky; 53 - Ust-Kalmansky; 54 - Ust-Pristansky; 55 - Khabarsky; 56 - Tselinny; 57 - Charyshsky; 58 - Shelabolikhinsky; 59 - Shipunovsky; 60 - Yarovoye Urban Okrug ; 6 I - Slavgorod Urban Okrug; 62 - Barnaul Urban Okrug.

We surveyed the fields with the following crops: rapeseed (Brassica napus L. ssp. olifera Metzg.), buckwheat (Fagopyrum esculentum Moench.), ridged flax (Linum usitatissimum L.), common wheat (Triticum aestivum L.), common sunflower (Helianthus annuus L.), and oat (Avena sativa L.).

The studied fields were surveyed by the route method, which involved the study of the plot by examining it along two diagonals and four sides, in case the area did not exceed 20.0 hectares. Larger fields were divided into plots of 20.0 hectares before 
the survey. The areas adjacent to the roads were examined most carefully, since it is often from the road that the field becomes infested.

We used the ArcGis program to compile original maps for the main weed plant species (Fig. 2).

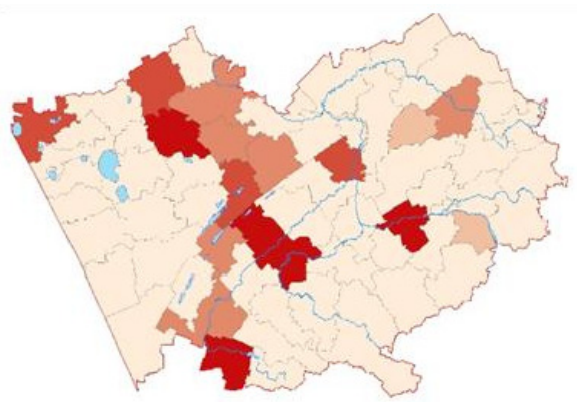

Amaranthus retroflexus

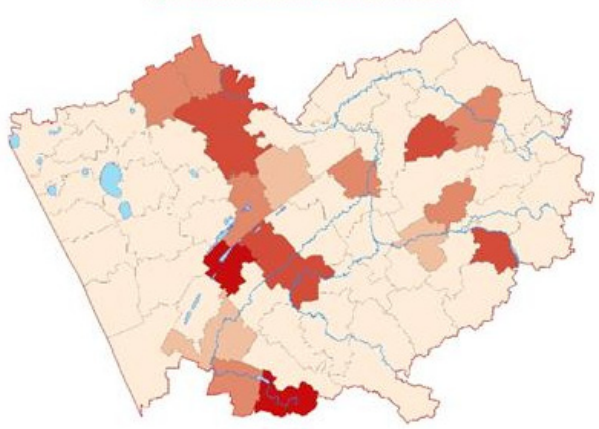

Echinochloa crusgalli

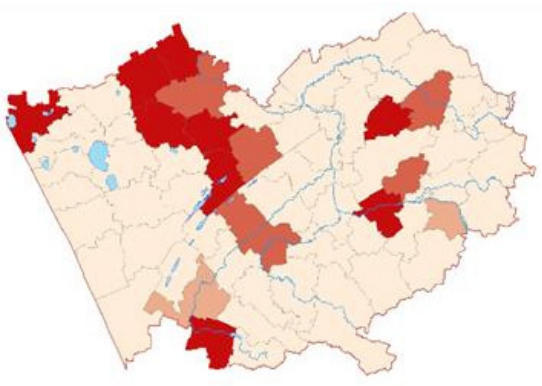

Convolvulus arvensis

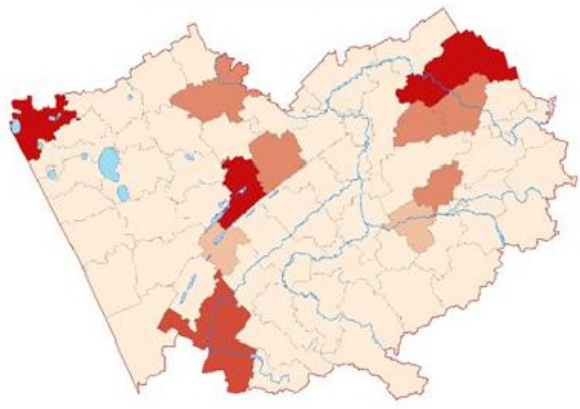

Fallopia convolvulus

\begin{tabular}{|c|c|}
\hline & $0-25$ \\
\hline & $26-50$ \\
\hline & $51-75$ \\
\hline & $76-100$ \\
\hline
\end{tabular}

Figure 2. Frequency rate of the main weed plant species in the territory of Altai krai (data from 2018-2019). Color stands for the frequency rate (\%)

\section{Results}

On the basis of the collected materials, we compiled a list of weed plant species found in the agrocenoses of Altai Krai. The list consists of 45 species belonging to 44 genera and 18 families. Some species on the list are particularly dangerous weeds (Hejda et al. 2017; Foxcroft et al. 2017; Mang et al. 2018; Matouskova et al. 2019) and require more in-depth study. The angiosperm families are arranged following 
the A.L. Takhtadzhyan system (1987). Genera and species are listed alphabetically. The species names are verified in accordance with the "Vascular Plants of Russia and Adjacent States (the Former USSR)" summary by S.K. Cherepanov (1995) and "Abstract of the Altai Krai flora" (Silantyeva 2013). Below is a summary list of species for the studied agrocenoses; adventitious plant species are marked with an asterisk "*" (Table 1).

Table 1. Frequency of weed plant species estimated during the survey of agrocenoses by the districts of Altai Krai (\%)

\begin{tabular}{|c|c|c|c|c|c|c|c|c|}
\hline № & Species & Wheat & Rapeseed & Flax & Buckwheat & Sunflower & Oat & Average \\
\hline$\overline{\text { Dis }}$ & tricts Number & 9 & 11 & 10 & 5 & 3 & 2 & \\
\hline Fiel & ds Number & 102 & 121 & 117 & 34 & 10 & 6 & \\
\hline \multicolumn{9}{|c|}{ Caryophyllaceae Juss. } \\
\hline 1 & $\begin{array}{l}\text { Oberna behen (J.) } \\
\text { Ikonn }\end{array}$ & 3.4 & 16.1 & 1.0 & - & - & 50.0 & 11.8 \\
\hline \multicolumn{9}{|c|}{ Amaranthaceae Juss. } \\
\hline 2 & $\begin{array}{l}\text { Amaranthus } \\
\text { retroflexus } \mathrm{L} .\end{array}$ & 29.6 & 47.1 & 39.6 & 38.8 & 33.3 & 50.0 & 39.7 \\
\hline \multicolumn{9}{|c|}{ Chenopodiaceae Vent. } \\
\hline 3 & ${ }^{\star}$ Atriplex patula L. & 4.5 & 5.6 & 3.4 & - & - & - & 2.2 \\
\hline 4 & $\begin{array}{l}\text { Chenopodium } \\
\text { album L. }\end{array}$ & 26.5 & 21.5 & 27.1 & 14.7 & 22.2 & - & 18.7 \\
\hline \multicolumn{9}{|c|}{ Polygonaceae Juss. } \\
\hline 5 & $\begin{array}{l}\text { Fagopyrum } \\
\text { tataricum (L.) } \\
\text { Gaertn. }\end{array}$ & 13.7 & 0.4 & 4.2 & 44.9 & 33.3 & - & 16.1 \\
\hline 6 & $\begin{array}{l}{ }^{\star} \text { Fallopia } \\
\text { convolvulus (L.) Á. } \\
\text { Löve }\end{array}$ & 66.5 & 43.1 & 56.9 & 62.0 & 33.3 & 75.0 & 56.1 \\
\hline 7 & $\begin{array}{l}\text { Polygonum } \\
\text { aviculare } \mathrm{L} .\end{array}$ & 1.7 & - & - & - & - & - & 0.3 \\
\hline 8 & $\begin{array}{l}\text { Persicaria scabra } \\
\text { (Moench) Mold }\end{array}$ & 7.4 & 11.6 & 14.1 & 4.0 & - & - & 6.2 \\
\hline \multicolumn{9}{|c|}{ Brassicaceae Burnett. } \\
\hline 9 & $\begin{array}{l}\text { Berteroa incana (L.) } \\
\text { DC. }\end{array}$ & 2.7 & 16.7 & 1.6 & 14.7 & - & 12.5 & 8.0 \\
\hline 10 & $\begin{array}{l}{ }^{*} \text { Capsella bursa- } \\
\text { pastoris (L.) Medik. }\end{array}$ & 13.4 & 3.7 & 3.4 & - & - & - & 4.6 \\
\hline 11 & $\begin{array}{l}{ }^{\star} \text { Lepidium ruderale } \\
\text { L. }\end{array}$ & 6.7 & 1.8 & 2.8 & 16.0 & - & - & 3.8 \\
\hline 12 & $\begin{array}{l}{ }^{*} \text { Neslia paniculata } \\
\text { (L.) Desv }\end{array}$ & - & 1.6 & - & - & - & - & 0.02 \\
\hline 13 & $\begin{array}{l}{ }^{\star} \text { Sisymbrium loeselii } \\
\text { L. }\end{array}$ & 3.1 & 20.5 & 18.0 & - & - & - & 6.9 \\
\hline 14 & ${ }^{\star}$ Thlaspi arvense L. & 0.1 & - & - & - & - & - & 0.0 \\
\hline
\end{tabular}




\begin{tabular}{|c|c|c|c|c|c|c|c|c|}
\hline № & Species & Wheat & Rapeseed & Flax & Buckwheat & Sunflower & Oat & Average \\
\hline \multicolumn{9}{|c|}{ Malvaceae Juss. } \\
\hline 15 & $\begin{array}{l}\text { Malva pusilla } \\
\text { Smith. }\end{array}$ & - & 15.7 & 1.6 & - & - & - & 2.9 \\
\hline \multicolumn{9}{|c|}{ Cannabaceae Mart. } \\
\hline 16 & $\begin{array}{l}{ }^{*} \text { Cannabis ruderalis } \\
\text { Janisch. }\end{array}$ & - & 2.0 & - & 4.0 & - & - & 1.0 \\
\hline \multicolumn{9}{|c|}{ Euphorbiaceae Juss. } \\
\hline 17 & $\begin{array}{l}\text { Euphorbia virgata } \\
\text { Waldst. \& Kit. }\end{array}$ & 36.0 & 24.8 & 19.7 & 14.7 & 11.1 & - & 17.7 \\
\hline \multicolumn{9}{|c|}{ Fabaceae Lindl. } \\
\hline 18 & Vicia cracca L. & 4.1 & - & 14.6 & - & - & - & 3.1 \\
\hline 19 & $\begin{array}{l}\text { Lathyrus tuberosus } \\
\text { L. }\end{array}$ & 27.5 & 7.5 & 1.0 & - & - & - & 6.0 \\
\hline
\end{tabular}

Geraniaceae Juss.

20 Erodium cicutarium $4.4 \quad 15$. (L.) L'Hér.

5.4

$16.7-$

$25.0 \quad 10.2$

Rubiaceae Juss.

$21{ }^{*}$ Galium aparine L. $\quad 6.8 \quad 17$. Convolvulaceae Juss.

$$
\text { arvensis } \mathrm{L} \text {. }
$$

$2.4 \quad 6.7$

Boraginaceae Juss.

23 Cynoglossum officinale L.

$24{ }^{\star}$ Echium vulgare L. 1.7

25 Lappula squarrosa 10.6 (Retz.) Dumort.

$26{ }^{\star}$ Lycospis arvensis $\mathrm{L}$. -

Scrophulariaceae Juss.

27 Linaria vulgaris L. $\quad 2.2 \quad 7.8$

12.1

$1.3 \quad-$

$19.9 \quad 4.0$

8.3

PlantaginaceaeJuss.

28 Plantago major L. $2.6 \quad 0.4$

0.4

$-\quad-$

Lamiaceae Mart.

29 Stachys palustris L. 2.2

30 Lamium album L. - $\quad 3.4$

3.4

Asteraceae Dum.

31 Achillea millefolium $1.7 \quad 1.3$

$\mathrm{L}$.

1.3

$29.3-$

32 Artemisia scoparia 3.7 Waldst. \& Kit.

33 Artemisia vulgaris L. $3.7 \quad 13.7$

34 Cirsium setosum 2.6

(Willd.) Bess

$35{ }^{\star}$ Conyza canadensis 5.4

$$
\text { (L.) Cronq. }
$$

36 Crepis tectorum L. -

37 Sonchus arvensis L. -

$\begin{array}{lll}- & 25.0 & 6.3\end{array}$

$-$




\begin{tabular}{|c|c|c|c|c|c|c|c|c|}
\hline № & Species & Wheat & Rapeseed & Flax & Buckwheat & Sunflower & Oat & Average \\
\hline 38 & $\begin{array}{l}{ }^{*} \text { Tripleurospermum } \\
\text { perfratum (Merat) } \\
\text { M. Lainz }\end{array}$ & 8.7 & 3.7 & 4.2 & 8.0 & - & - & 4.1 \\
\hline \multicolumn{9}{|c|}{ Poaceae Sturm. } \\
\hline 39 & ${ }^{*}$ Avena fatua $\mathrm{L}$. & 23.5 & 11.4 & 8.3 & 40.0 & - & - & 13.9 \\
\hline 40 & $\begin{array}{l}{ }^{*} \text { Echinochloa } \\
\text { crusgalli (L.) Beauv. }\end{array}$ & 45.7 & 25.9 & 58.8 & 21.3 & 16.7 & 75.0 & 40.6 \\
\hline 41 & $\begin{array}{l}{ }^{*} \text { Eriochloa villosa } \\
\text { (Thubg) Knuth }\end{array}$ & - & 2.8 & - & - & - & - & 0.5 \\
\hline 42 & $\begin{array}{l}{ }^{*} \text { Panicum } \\
\text { miliaceum subsp. } \\
\text { ruderale (Kitag.) } \\
\text { Tzlel. }\end{array}$ & 38.6 & 37.1 & 20.9 & 42.9 & 8.3 & 100 & 41.3 \\
\hline 43 & $\begin{array}{l}{ }^{*} \text { Setaria pumila } \\
\text { (Poir.) Schult }\end{array}$ & 35.4 & 40.3 & 45.8 & 29.3 & 44.4 & 25.0 & 36.7 \\
\hline \multirow[t]{2}{*}{44} & $\begin{array}{l}{ }^{\star} \text { Setaria viridis (L.) } \\
\text { P.Beauv. }\end{array}$ & 15.3 & 24.6 & 27.7 & 17.6 & 33.3 & - & 19.8 \\
\hline & Total & 37 & 42 & 37 & 24 & 13 & 12 & 52 \\
\hline
\end{tabular}

\section{Discussion}

The largest number of species accounts for the Asteraceae (17.8\%), Poaceae (13.3\%), and Brassicaceae (13.3\%) families (Table 2). This distribution is typical for disturbed areas. The Asteraceae family is represented by Cirsium arvense, Tripleurospermum inodorum, Sonchus arvensis, and Conyza canadensis. The Poaceae family is represented by Echinochloa crus galli, Setaria pumila, Panicum miliaceum, and Eriochloa villosa. The Brassicaceae family is represented by Neslia paniculata, Sisymbrium loeselii, and Capsella bursa-pastoris. Almost all of the listed species are frequent and even aggressive weeds. Other families are characterized by less significant diversity. Half of the enumerated families are monospecies.

The adventitious fraction is represented by 18 species of 17 genera and 7 families (Table 3). The largest number of species accounts for the Poaceae family (33.3\%). The Brassicaceae family is characterized by a slightly lower percentage of participation in the adventitious flora (27.7\%). Other families are not so well represented (by 1-2 species each). Comparing the parameters of the systematic analysis of the agrocenoses flora as a whole and its adventitious fraction, we concluded that the Poaceae, Brassicaceae, and Asteraceae families are dominant for both the adventitious flora and the flora of agrocenoses in Altai Krai.

We examined 102 wheat fields in 9 districts of Altai Krai (Table 1). The total number of identified weed species in wheat crops was 39. The most infested were wheat crops in Kamenskiy and Kytmanovskiy districts (20 species per district). The least infested fields were located in Zarinskiy and Tyumentsevskiy districts. 
In the studied districts, 10 weed species were the most frequent for the agrocenoses, but the frequency rate of Convolvulus arvensis (45.7\%), Fallopia convolvulus (66.5\%), Echinochloa crusgalli (71.3\%) exceeds the frequency rate of other species. The remaining 29 species do not play a significant role in the flora of wheat agrocenoses, as their frequency rate does not reach $20.0 \%$.

We identified 44 weed species in 121 rapeseed fields in 16 districts of the region. Species that have a frequency rate of $>20 \%$ constitute the basis of the weed flora

Table 2. Characteristics of weed families in agrocenoses of Altai Krai

\begin{tabular}{llll}
\hline Family & $\begin{array}{l}\text { Number of } \\
\text { Genera }\end{array}$ & $\begin{array}{l}\text { Number of } \\
\text { Species }\end{array}$ & $\begin{array}{l}\text { Percentage of } \\
\text { Participation, \% }\end{array}$ \\
\hline Asteraceae & 7 & 8 & 17.8 \\
Brassicaceae & 6 & 6 & 13.3 \\
Poaceae & 5 & 6 & 13.3 \\
Boraginaceae & 4 & 4 & 8.9 \\
Polygonaceae & 3 & 4 & 8.9 \\
Chenopodiaceae & 2 & 2 & 4.4 \\
Fabaceae & 2 & 2 & 4.4 \\
Caryophyllaceae & 2 & 2 & 4.4 \\
Lamiaceae & 2 & 2 & 4.4 \\
Malvaceae & 1 & 1 & 2.2 \\
Euphorbiaceae & 1 & 1 & 2.2 \\
Cannabaceae & 1 & 1 & 2.2 \\
Geraniaceae & 1 & 1 & 2.2 \\
Rubiaceae & 1 & 1 & 2.2 \\
Convolvulacea & 1 & 1 & 2.2 \\
Scrophulariaceae & 1 & 1 & 2.2 \\
Amaranthaceae & 1 & 1 & 2.2 \\
Plantaginaceae & 1 & 1 & 2.2 \\
Total & 42 & 45 & 100.0 \\
\hline & & &
\end{tabular}

Table 3. Characteristics of the families of the weed adventitious fraction in agrocenoses of Altai Krai

\begin{tabular}{llll}
\hline Family & $\begin{array}{l}\text { Number of } \\
\text { Genera }\end{array}$ & $\begin{array}{l}\text { Number of } \\
\text { Species }\end{array}$ & $\begin{array}{l}\text { Percentage of } \\
\text { participation, \% }\end{array}$ \\
\hline Poaceae & 5 & 6 & 33.3 \\
Brassicaceae & 5 & 5 & 27.8 \\
Asteraceae & 2 & 2 & 11.1 \\
Boraginaceae & 2 & 2 & 11.1 \\
Rubiaceae & 1 & 1 & 5.6 \\
Cannabaceae & 1 & 1 & 5.6 \\
Chenopodiaceae & 1 & 1 & 5.6 \\
Total & 17 & 18 & 100.0 \\
\hline
\end{tabular}


in rapeseed crops. The most frequent were Convolvulus arvensis (61.7\%), Fallopia convolvulus (43.1\%) and Amaranthus retroflexus (47.1\%). The remaining species did not play a significant role in these agrocenoses; many of them are represented by single specimens.

The survey of flax agrocenoses in 8 districts of the Altai Krai resulted in identification of 38 weed species in 117 fields. The most frequent weeds in flax crops were Convolvulus arvensis (55.65\%), Fallopia convolvulus (56.86\%), Echinochloa crusgalli (58.75\%), and Setaria pumila (45.79\%). The great majority of the encountered species was presented by 1 or 2 specimens.

During the 2019 field season, we examined 10 sunflower fields. The weed species diversity of these agrophytocenoses was similar to other crops (6-7 species). The highest frequency was recorded for the following species: Convolvulus arvensis (69.4\%), Stachys palustris (66.7\%) and Setaria pumila (44.4\%). The total number of species registered in agrocenoses was low - 14 species, however, 10 species have a high frequency, and therefore, form the basis of the weed flora in sunflower crops. We also detected that 4 species had the frequency rate less than $20.0 \%$ and do not play a prominent role in the flora of these agrocenoses.

When examining 6 oat fields, we identified 12 weed species. The most abundant were Convolvulus arvensis, Panicum miliaceum, Echinochloa crusgalli, and Fallopia convolvulus (75.0\%).

We checked 34 fields with buckwheat crops in 5 administrative districts and identified 25 weed species. We supposed that only 10 species formed the basis of the weed flora in buckwheat fields crops with a frequency rate of more than $20.0 \%$. The most frequent species were Convolvulus arvensis (81.3\%), Fallopia convolvulus (62\%), Fagopyrum tataricum (44.9\%), and Panicum miliaceum (44.2\%). Fields with the highest species diversity were registered in Loktevskoy (16 species), Mamontovskiy (12 species), and Rubtsovskiy districts (10 species). In other districts, the species diversity was not significant.

\section{Conclusion}

Thus, we can conclude that the aboriginal Convolvulus arvensis, Amaranthus retroflexus, and adventive species Fallopia convolvulus, Setaria pumila, Panicum miliaceum var. ruderale, and Echinochloa crusgalli were the most frequent and abundant weeds in the fields with oat, rapeseed, flax, sunflower, wheat, and buckwheat.

As reported in the previously published works (Terekhina 2000; Terekhina, Luneva 2018; Terekhina et al. 2018), the segetal flora of Altai Krai comprises 392 species, on the whole. However, in recent years, some species have disappeared and the floras of agrophytocenoses have become unified, which is probably associated with the active use of herbicides and other chemical products in crop protection. 


\section{References}

Burlakova LM (2007) Strategic land management in the management system for sustainable development of agricultural nature management. Altai Agrarian University Bulletin 10 (36): 5-9. [In Russian]

Cherepanov SK (1995) Vascular Plants of Russia and Adjacent States (the Former USSR). Saint Petersburg, 990 pp. [In Russian]

Foxcroft LC, Pyšek P, Richardson DM, Genovesi P, MacFadyen S (2017) Plant invasion science in protected areas: progress and priorities. Biological Invasions 19 (5): 1353-1378. https://doi.org/10.1007/s10530-016-1367-z

Hejda M, Štajerová K, Pyšek P (2017) Dominance has a biogeographical component: do plants tend to exert stronger impacts in their invaded rather than native range? Journal of Biogeography 44: 18-27. https://doi.org/10.1111/jbi.12801

Korolyuk AYu, Yegorova AV, Smelyanskiy IE, Filippova NV (2005) Structure of the vegetation cover of the steppe hummocks in the Altai foothills. Siberian Ecological Journal 6: 999-1011. [In Russian]

Mang T, Essl F, Moser D, Dullinger S (2018) Climate warming drives invasion history of Ambrosia artemisiifolia in central Europe. Preslia 90: 59-81. https://doi.org/10.23855/ preslia.2018.059

Matouškova M, Jurova J, Grulova D, Wajs-Bonikowska A, Renčo M, Sedlak V, Poračova J, Gogalova Z, Kalemba D (2019) Phytotoxic Effect of Invasive Heracleum mantegazzianum Essential Oil on Dicot and Monocot Species. Molecules 24(3): 425. https:// doi.org/10.3390/molecules24030425

Silantyeva MM (2013) Abstract of the Altai Krai flora. Barnaul, 520 pp. [In Russian]

Takhtadzhyan AL (1987) Angiosperms system. Leningrad, 440 pp. [In Russian]

Terekhina TA (2000) Anthropogenic phytosystems. Barnaul, 250 pp. [In Russian]

Terekhina TA, Luneva NN (2018) Distribution of weeds in the regions (at the example of Altai Krai and Leningrad oblast). Ecology and geography of plants and plant communities: proceedings of the IV International scientific conference (Yekaterinburg, 16-19 April 2018). Yekaterinburg, 935-939. [In Russian]

Terekhina TA, Ovcharova NV, Silantyeva MM (2018) Adventitious element in various types of plant communities in Altai Krai. Ecology and geography of plants and plant communities: proceedings of the IV International scientific conference (Yekaterinburg, 16-19 April 2018). Yekaterinburg, 939-945. [In Russian] 